\title{
OBRONA KONIECZNA A PRZESTĘPSTWO BÓJKI
}

Jedną z najbardziej kontrowersyjnych kwestii pojawiających się na gruncie instytucji obrony koniecznej jest kwestia dopuszczalności powoływania się na nia przez uczestnika bójki. Jak zauważa Andrzej Marek, zagadnienie to wywoływało daleko idące różnice zdań w doktrynie i orzecznictwie sądowym, szczególnie w okresie obowiązywania kodeksów karnych z 1932 r. i 1969 r., kiedy zagadnienie to było bardzo szeroko dyskutowane ${ }^{1}$. Obrona konieczna stanowi jedna z okoliczności wyłączających bezprawność czynu zabronionego. Okoliczności wyłączające bezprawność czynu zabronionego określane sa w karnistyce mianem kontratypów. Przed przystapieniem do szczegółowej analizy zagadnienia dopuszczalności powoływania się przez uczestnika bójki na działanie w obronie koniecznej należy w pierwszej kolejności odwołać się do kodeksowej regulacji instytucji obrony koniecznej. Została ona zdefiniowana w art. $25 \S 1$ Kodeksu karnego z 6 czerwca 1997 r. w następujący sposób: „Nie popełnia przestępstwa, kto w obronie koniecznej odpiera bezpośredni, bezprawny zamach na jakiekolwiek dobro chronione prawem". Wskazać jednak należy, iż istotną rolę precyzującą odgrywa także $\S 2$ art. 25 k.k., zgodnie z którym: „W razie przekroczenia granic obrony koniecznej, w szczególności, gdy sprawca zastosował sposób obrony niewspółmierny do niebezpieczeństwa zamachu, sąd może zastosować nadzwyczajne złagodzenie kary, a nawet odstapić od jej wymierzenia”. Analiza wyżej przytoczonych regulacji pozwala na stwierdzenie, że w polskim Kodeksie karnym sformułowane zostały dwie grupy warunków, jakie muszą zostać spełnione, aby w danej sytuacji można było mówić o obronie koniecznej. Są to mianowicie warunki uprawniające do podjęcia obrony koniecznej, określane niekiedy mianem warunków czy też cech zamachu, jak również warunki określające dozwolony prawem sposób realizowania obrony koniecznej, zwane także warunkami czy cechami obrony koniecznej.

Jak zauważa Marian Cieślak: „Aby powstała sytuacja obrony koniecznej, musi istnieć zamach. Rozumie się przez to zachowanie człowieka stwarzające niebezpieczeństwo dla dobra prawnego"2. Henryk Rajzman wychodzi z założenia, że: „Zamachem [...] jest każda człowiecza próba nadwyrężenia wartości przysługującej społeczeństwu lub jednostce"3. Zdaniem Barbary Namysłowskiej-Gabrysiak: „Zamach jest zachowaniem człowieka powoduja-

1 A. Marek, Obrona konieczna w prawie karnym. Teoria i orzecznictwo, Warszawa 2008, s. 75.

${ }^{2}$ M. Cieślak, Polskie prawo karne. Zarys systemowego ujęcia, Warszawa 1995, s. 219.

${ }^{3}$ H. Rajzman, Kodeks karny. Wytaczenie odpowiedzialności karnej, Warszawa 1970, s. 9. 
cym bezpośrednie zagrożenie dla dobra chronionego prawem” ${ }^{4}$. Również Michał Królikowski oraz Robert Zawłocki stoją na stanowisku, że: „Zamachem jest zachowanie kryjace w sobie niebezpieczeństwo dla jakiegokolwiek dobra chronionego przez prawo”. M. Cieślak podkreśla, że: „Semantycznie "zamach“ kojarzy się raczej z zachowaniem czynnym, atakiem. Stąd różnice zdań w kwestii, czy zamach [...] może polegać również na zaniechaniu. Biorąc pod uwagę funkcję obrony koniecznej jako działania skierowanego ku ochronie prawa należy przyjąć, że również zaniechanie można uznać za zamach, ale tylko wtedy, gdy grozi ono sprowadzeniem kryminalnie bezprawnego skutku lub oznacza utrzymywanie kryminalnie bezprawnego stanu, choćby wywołanego w sposób nie-bezprawny[...]"6. Pogląd ten podziela także A. Marek, uznając, że stanowisko dopuszczające możliwość zamachu w formie jakiegokolwiek zachowania się (działania lub zaniechania), które stwarza bezpośrednie niebezpieczeństwo dla dobra społecznego lub jednostki, jest stanowiskiem w pełni słusznym$^{7}$. Autor ten stwierdza, że stanowisko to: „Nie zawęża [...] apriorycznie pojęcia zamachu i dopuszczalności obrony koniecznej, w zależności od analizy takich, czy innych przykładów wziętych z praktyki, wychodząc z założenia, że bogactwo zdarzeń w rzeczywistości społecznej może zawsze nasuwać nowe, nieprzewidziane stany faktyczne"8. Stanowisko dopuszczające możliwość zamachu w formie zarówno działania, jak i zaniechania podziela także B. Namysłowska-Gabrysiak ${ }^{9}$. Roman Góral podkreśla z kolei, że pojęcie zamachu jest obszerniejsze od pojęcia napadu czy ataku ${ }^{10}$.

Zamachem uprawniajacym daną osobę do podjęcia obrony koniecznej jest tylko taki zamach, który jest zamachem faktycznym, bezpośrednim oraz bezprawnym. Zamach jest faktyczny, jeśli ma on miejsce w świecie zewnętrznym. Jak zauważa Łukasz Pohl: „Czasem zdarza się, że mimo braku zamachu człowiek podejmuje obronę przed zamachem, którego istnienie sobie mylnie wyobraził. W takiej sytuacji, nazywanej tradycyjnie, aczkolwiek nietrafnie, urojeniem zamachu, o obronie koniecznej - z uwagi właśnie na niespełnienie warunku faktyczności zamachu - mowy być nie może, co nie oznacza automatycznego pociagnięcia sprawcy urojonej obrony koniecznej do odpowiedzialności karnej za zrealizowany w drodze takiej obrony czyn zabroniony. Jeśli bowiem mylne wyobrażenie rzeczonego sprawcy odnośnie do istnienia zamachu zostanie uznane za usprawiedliwione, to nie będzie można mu przypisać winy, gdyż usprawiedliwiony błąd co do kontratypu, a z nim mamy w omawianej sytuacji do czynienia, taką właśnie konsekwencję w polskim prawie karnym wywołuje"11.

${ }^{4}$ B. Namysłowska-Gabrysiak, Prawo karne - część ogólna, Warszawa 2008, s. 114.

${ }^{5}$ M. Królikowski, R. Zawłocki, Prawo karne, Warszawa 2015, s. 256.

${ }^{6}$ M. Cieślak, op. cit., s. 219.

${ }^{7}$ A. Marek, Obrona konieczna $w$ prawie karnym na tle teorii i orzecznictwa Sqdu Najwyższego, Warszawa 1979, s. 39.

8 Ibidem

${ }^{9}$ B. Namysłowska- Gabrysiak, op. cit., s. 114.

10 R. Góral, Obrona konieczna w praktyce, Warszawa 2011, s. 34.

${ }^{11}$ Ł. Pohl, Prawo karne. Wyktad części ogólnej, Warszawa 2013, s. 241-242. 
O bezpośredniości zamachu można mówić jedynie wtedy, gdy napastnik, dopuszczając się zamachu, zmierza bezpośrednio do naruszenia dobra chronionego prawem. Jak słusznie podkreśla Ł. Pohl: „W sytuacji [...], gdy zamach jest umyślną próbą naruszenia dobra prawnego, z bezpośredniością zamachu mamy do czynienia wtedy, gdy sprawca wkroczy w fazę usiłowania dokonania czynu zabronionego. W wypadku zaś, gdy zamach jest zachowaniem nieumyślnym, bezpośredniość zamachu zachodzi wówczas, gdy sprawca swoim zachowaniem wytworzył realne (konkretne) niebezpieczeństwo naruszenia dobra chronionego prawem” ${ }^{2}$. Zdaniem tego autora: „Trafnie podkreśla się, że zamach osiaga stadium bezpośredniości, gdy jego kontynuacja w razie braku zewnętrznej ingerencji, np. pochodzącej ze strony dysponenta zagrożonego dobra prawnego lub osoby trzeciej, prowadzi niemalże nieuchronnie do naruszenia tego dobra"13. Zauważyć należy, że w sytuacji gdy obrona podjęta zostanie, zanim zamach osiagnie fazę bezpośredniości, nie mamy do czynienia z obroną konieczna, lecz z przekroczeniem jej granic, określanym $\mathrm{w}$ doktrynie prawa karnego mianem ekscesu ekstensywnego. Podobnie eksces ekstensywny zachodzi wtedy, gdy obrona zostanie podjęta w momencie, gdy zamach już się zakończył.

Zamach spełnia natomiast warunek bezprawności tylko wtedy, gdy napastnik swoim zachowaniem dopuści się przekroczenia normy prawnej. Nie sposób nie zauważyć, że z faktu, iż zamach musi spełniać warunek bezprawności, wynika, że zamachem może być jedynie zachowanie się człowieka, a nie np. działanie sił przyrody. M. Cieślak podkreśla, że „[...] bezprawność zamachu oznaczać musi naruszenie prawa, ściślej - jakiejśs normy prawnej zobowiązującej, a więc obowiązku prawnego. Bezsporne jest [...], że nie musi tu chodzić aż o przepisy prawa karnego, wystarczy bezprawność z punktu widzenia jakiejkolwiek dziedziny prawa" ${ }^{14}$. Pogląd ten podziela także Tadeusz Bojarski ${ }^{15}$, jak również Marcin Berent oraz Marian Filar ${ }^{16}$. M. Cieślak zwraca uwagę na to, że w doktrynie prawa karnego panuje zgoda co do tego, że zamach nie musi być zawiniony, albowiem może pochodzić on także od osoby niepoczytalnej czy też nieletniego ${ }^{17}$.

M. Cieślak wskazuje, że „[...] samo pojęcie obrony może być interpretowane dwojako. W interpretacji subiektywnej jest to działanie świadomie i celowo skierowane ku odparciu zamachu. W interpretacji obiektywnej istotne byłoby tylko to, czy działanie zagrożonego zamachem jest faktycznie przeciwstawne zamachowi, niezależnie od tego, czy napadnięty zdaje sobie sprawę z tego, że odpiera atak. Pomijając sztuczność i małe w ogóle prawdopodobieństwo tej drugiej sytuacji, należy opowiedzieć się raczej za interpretacją subiektywna, jako bardziej odpowiadająca zwykłym intuicjom semantycznym sformułowania art. $22 \S 1$ [Kodeksu karnego z 19 kwietnia 1969 r. - przyp. P.B.], zwłasz-

\footnotetext{
12 Ibidem, s. 242.

13 Ibidem.

14 M. Cieślak, op. cit., s. 220.

15 T. Bojarski, Polskie prawo karne. Zarys części ogólnej, Warszawa 2012, s. 166.

${ }_{16}$ M. Berent, M. Filar, w: M. Filar (red.), Kodeks karny. Komentarz, Warszawa 2014, s. 99.

17 M. Cieślak, op. cit., s 220.
} 
cza, gdy chodzi o znaczenie zwrotów «obrona» i «odpiera» (argument z kręgu wykładni słownej)"18.

Wśród warunków, jakie musi spełniać obrona, aby można ją było określić mianem obrony koniecznej, wskazać należy przede wszystkim warunek konieczności. Alicja Grześkowiak zwraca uwage na to, że: „Obrona powinna być konieczna i to kryterium wytycza przedmiotowe granice tej instytucji. Zachowanie odpierające zamach, ale niemieszczące się w ramach konieczności, nie powoduje uchylenia bezprawności zachowania z tytułu obrony koniecznej. W pierwszej kolejności, konieczność obrony wynikać powinna z rzeczywistej potrzeby odparcia zamachu. Obrona musi być więc niezbędna do odparcia zamachu. Konieczność oznacza zatem, że dla obrony dobra prawnego niezbędna jest odpowiedź na zamach”19. Leszek Wilk wskazuje, że: „Obrona musi być konieczna przede wszystkim w sensie technicznym, co oznacza używanie środków i sposobów koniecznych do odparcia ataku, nie oznacza to natomiast wymogu używania przez broniącego się identycznego narzędzia lub identycznego sposobu jak napastnik. Można zatem odpierać atak prowadzony gołymi rękami za pomocą niebezpiecznych narzędzi, jeśli jest to $\mathrm{w}$ danej sytuacji konieczne, np. atakującym jest młody silny człowiek, a broniącym się osoba starsza" ${ }^{20}$.

Ł. Pohl zwraca uwagę na to, że: „W doktrynie prawa karnego i w orzecznictwie sądowym dają się zauważyć dwa w pewnym zakresie konkurencyjne ujęcia warunku konieczności obrony. Zdaniem jednych z koniecznością obrony mamy do czynienia wtedy, gdy broniący się nie ma możliwości uniknięcia konfrontacji z napastnikiem, zdaniem drugich - można przyjąć konieczność obrony także w sytuacjach, kiedy to broniący ma taka możliwość. W polskiej doktrynie prawa karnego i w orzecznictwie sądów polskich zdecydowanie przeważa drugie z zarysowanych stanowisk, którego zwolennicy nie bez racji wskazuja, że przyjęcie konkurencyjnego rozwiąania promuje postawy tchórzliwe, sprzeczne z idea, w myśl której prawo nie powinno ustępować przed bezprawiem - ideą uzasadniająca i racjonalizująca prawo człowieka do odpierania zamachu na dobro prawne w drodze obrony koniecznej" ${ }^{21}$. Ponadto wskazać należy, że obrona konieczna powinna być skierowana wyłącznie przeciwko osobie atakującej, a nie jakiejkolwiek innej osobie.

Nadto konieczne jest, aby sposób realizowania obrony koniecznej był współmierny do niebezpieczeństwa zamachu, w przeciwnym razie mamy bowiem do czynienia z przekroczeniem granic obrony koniecznej, noszacym w nauce prawa karnego nazwę ekscesu intensywnego. Tomasz Tabaszewski, zwraca uwage na to, że „[...] eksces intensywny zachodzi przy użyciu bardziej szkodliwego dla napastnika środka obrony, spośród równie skutecznych. Oznacza to prawo do użycia środka najskuteczniejszego (gdyż nie można nakładać obowiązku wyboru środka mniej skutecznego i jednocześnie uznawać prawa do skutecz-

\footnotetext{
18 Ibidem, s. 222 .

19 A. Grześkowiak, w: eadem, K. Wiak (red.), Kodeks karny. Komentarz, Warszawa 2014, s. 169

${ }^{20}$ L. Wilk, w: T. Dukiet-Nagórska (red.), Prawo karne. Część ogólna, szczególna i wojskowa, Warszawa 2014, s. 146-147.

21 Ł. Pohl, op. cit., s. 243-244.
} 
nej obrony) i obowiązek wyboru środka najmniej niebezpiecznego spośród tak wyodrębnionej grupy środków”22. Ten sam autor stwierdza, że: „Ocena, czy zachodzi eksces intensywny, musi być dokonana nie przez pryzmat skutków, lecz ex ante, z punktu widzenia obiektywnego obserwatora" ${ }^{23}$. Jak zauważa Anna Zientara, przekroczenie granic obrony koniecznej powoduje, że czyn jest bezprawny, a co za tym idzie, może być uznany za przestępny ${ }^{24}$.

Prawnokarną konsekwencją działania w obronie koniecznej jest to, iż czynowi podejmowanemu w jej ramach nie można przypisać cechy bezprawności. Jarosław Warylewski zauważa, że: „Bezprawność zachowania albo jej brak sa decydujące dla ponoszenia odpowiedzialności karnej i nie chodzi tu w żadnym razie o jakąkolwiek bezprawność. Ta wystarczy faktycznie, aby uznać, że zamach spełniał warunki przewidziane w art. $25 \mathrm{k} . \mathrm{k}$. Jednak, aby ponosić odpowiedzialność karna, albo żeby od niej uwolnić, musi wystapić bezprawność kryminalna albo odpowiednio - bezprawności kryminalnej musi zabraknąć" ${ }^{25}$. Jak wskazuje $€$. Pohl: „Broniący się w drodze obrony koniecznej dopuszcza się [...] czynu zabronionego. Z uwagi jednak na sytuację, w której zostaje on popełniony - właśnie obrony koniecznej - czyn ten nie jest czynem bezprawnym. W przypadku obrony koniecznej mamy więc do czynienia z niebezprawnym (legalnym) przekroczeniem normy sankcjonowanej w prawie karnym [...]"26. Choć pojęcie „kontratyp” definiowane bywa często jako okoliczność wyłączająca bezprawność czynu zabronionego, to jednak M. Cieślak zwraca uwagę na to, że: „[...] słowo «wyłącza» nie jest w pełni adekwatne dla określenia funkcji kontratypu. Może ono bowiem sugerować, że istnieje najpierw bezprawność, która następnie dopiero «wyłącza», czy "uchyla» kontratyp. Tymczasem czyn popełniony w warunkach kontratypu jest od samego początku pozbawiony cechy kryminalnej bezprawności - właśnie ze względu na neutralizujące działanie kontratypu"27.

Przestępstwo bójki zostało natomiast stypizowane w art. 158 k.k. § 1 tego artykułu; stanowi, że „Kto bierze udział w bójce lub pobiciu, w którym naraża się człowieka na bezpośrednie niebezpieczeństwo utraty życia albo nastapienie skutku określonego w art. $156 \S 1$ lub w art. 157 § 1 , podlega karze pozbawienia wolności do lat 3”. Jak wskazuje Magdalena Budyn-Kulik: „Przez bójkę rozumie się zdarzenie, w którym biorą udział co najmniej trzy osoby, z których każda jednocześnie atakuje i broni się (nie można wskazać strony wyłącznie ofensywnej i wyłącznie defensywnej)"28. Również Krzysztof Wiak podkreśla, że: „Bójką jest starcie co najmniej trzech osób, z których każda występuje rów-

${ }^{22}$ T. Tabaszewski, Eksces intensywny obrony koniecznej $w$ orzecznictwie, „Prokuratura i Prawo" 2010, nr 12 , s. 72 .

${ }^{23}$ Ibidem, s. 72.

${ }^{24}$ A. Zientara, Prawo karne materialne, Warszawa 2012, s. 112.

${ }_{25} \mathrm{~J}$. Warylewski, Zasada ustawowej określoności przesłanek odpowiedzialności karnej a kontratypy pozaustawowe, w: J. Majewski (red.), Okoliczności wytaczajace bezprawność czynu. Materiaty IV Bielańskiego Kolokwium Karnistycznego, Wyd. Towarzystwa Naukowego Organizacji i Kierownictwa, Stowarzyszenie Wyższej Użyteczności Dom Organizatora, Toruń 2008, s. 31.

${ }^{26}$ Ł. Pohl, op. cit., s. 245-246.

${ }^{27}$ M. Cieślak, op. cit., s. 215.

${ }^{28}$ M. Budyn-Kulik, w: M. Mozgawa (red.), Kodeks karny. Komentarz, Warszawa 2014, s. 399. 
nocześnie w roli atakującego i broniącego się" ${ }^{29}$. Zwraca na to uwagę także M. Królikowski ${ }^{30}$. Andrzej Lisowski stwierdza natomiast, że: „Zgodnie z jednoznacznym stanowiskiem wyrażonym wielokrotnie w orzecznictwie Sądu Najwyższego oraz poglądami teoretyków prawa karnego, bójka jest takie zachowanie się, w którym następuje zwada, starcie pomiędzy osobami (których jest co najmniej trzy), każdy zaś z jej uczestników występuje w podwójnym charakterze, raz jako napastnik, raz jako napadnięty" ${ }^{31}$. Krzysztof Krajewski zauważa, że: „Najogólniej rzecz ujmując, przestępstwo określane mianem udziału w bójce [...] jest to zajście, w którym ludzie zadają sobie ciosy rękami, czy też za pomocą różnorodnych narzędzi, kopią się, mocuja, popychają itp. Bójka to zajście, w którym biorą udział co najmniej trzy osoby wzajemnie się atakujące. Oznacza to, że w przypadku bójki brak jest wyraźnego podziału na przeciwstawne strony zajścia: każdy uczestnik jest jednocześnie atakujacym i atakowanym, w związku z czym każdy jest sprawcą przestępstwa [...], chociaż każdy może być równocześnie de facto poszkodowanym w zajściu"32. Maciej Szwarczyk zwraca uwagę na to, że w przypadku przestępstwa bójki: „Czyn sprawców polega na »braniu udziału w bójce lub pobiciu«, przez co należy rozumieć nie tylko aktywne uczestnictwo, w którymś z tych zajść, przybierajace postać zadawania ciosów. Udział w bójce lub pobiciu będzie stanowić także zachowanie polegające na "zagrzewaniu" uczestników do walki, np. poprzez okrzyki czy też inne działania, które z uwagi na charakter tych zdarzeń moga potęgować ich niebezpieczeństwo" ${ }^{33}$. Pogląd ten podziela także Jacek Giezek ${ }^{34}$. Warto w tym miejscu zwrócić uwagę na wyrok Sądu Najwyższego z 19 maja 1976 r. (V KR 68/76), w którym Sąd ten podkreślił, że „Odpowiedzialność na podstawie art. 158 k.k. [Kodeks karny z 1969 r. - przyp. P.B.] zachodzi nie tylko wówczas, gdy skutki wymienione w tym przepisie dotknęły ofiarę pobicia, ale również wówczas, gdy skutki te dotknęły jednego ze sprawców pobicia, co może się zdarzyć zwłaszcza z akcją obronną bitego lub innej osoby".

Właśnie z uwagi na fakt, że mianem bójki określa się starcie, w którym to co najmniej trzy osoby atakują się wzajemnie i brak jest podziału na stronę atakująca i stronę atakowana, co do zasady nie jest, w moim przekonaniu, możliwe powoływanie się przez uczestnika bójki wobec pozostałych jej uczestników na fakt, iż działa on w obronie koniecznej. Wynika to bowiem z samej istoty tego przestępstwa. Skoro wszyscy uczestnicy bójki jednocześnie atakuja i bronią się, to uznać należy, że każdy z nich dopuszcza się bezprawnego zamachu na dobra prawne pozostałych jej uczestników, w związku z czym nie może się powołać na fakt, iż działa on w obronie koniecznej. Gdyby uznać inaczej,

${ }^{29}$ K. Wiak, w: A. Grześkowiak, K. Wiak (red.), Kodeks karny. Komentarz, Warszawa 2014, s. 681 .

${ }^{30}$ M. Królikowski, w: idem, R. Zawłocki (red.), Kodeks karny. Część szczególna, t. 1: Komentarz. Art. 117-221, Warszawa 2013, s. 285.

31 A. Lisowski, Przestęstwa przeciwko zdrowiu i życiu. Orzecznictwo Sadu Najwyższego, Toruń 1994, s. 232.

${ }^{32}$ K. Krajewski, Bójka i pobicie. Analiza kryminologiczna, Kraków 1988, s. 9.

${ }^{33}$ M. Szwarczyk, w: T. Bojarski (red.), Kodeks karny. Komentarz, Warszawa 2013, s. 392.

${ }_{34}$ J. Giezek, w: idem (red.), Kodeks karny. Część szczególna. Komentarz, Warszawa 2014, s. 231 . 
a mianowicie, że uczestnikowi bójki przysługuje prawo powołania się na kontratyp obrony koniecznej wobec pozostałych jej uczestników, doszłoby, moim zdaniem, do przekreślenia sensu istnienia tego przestępstwa, albowiem wtedy należałoby przyjać, że każdy z uczestników bójki broniący się przed atakiem działa w obronie koniecznej, a to wyłączałoby możliwość przypisania mu odpowiedzialności karnej.

Pogląd ten podziela także R. Góral, uznając, że przyznanie uczestnikowi bójki bez ograniczeń prawa do stosowania obrony koniecznej przekreśliłoby sens istnienia art. 158 k.k., gdyż żaden z jej uczestników nie mógłby odpowiadać za przestępstwo ${ }^{35}$. Podobne stanowisko prezentuje Paweł Daniluk, stwierdzając, że: „Co do zasady należy przyjąć, że uczestnik bójki nie może powoływać się na kontratyp obrony koniecznej. Wynika to z konstrukcji tego przestępstwa, unormowanego aktualnie w art. 158 i 159 k.k., która polega na tym, że co najmniej trzy osoby uczestniczą w starciu, podczas którego atakuja się wzajemnie. Nie można tu więc przeprowadzić podziału uczestników bójki na atakujących i broniących się, czy też - innymi słowy - na napastników i napadniętych. Wszyscy oni bowiem jednocześnie atakują i bronią się. W takiej sytuacji żadnemu z uczestników bójki obrona konieczna przysługiwać nie może, gdyż każdy z nich dopuszcza się bezprawnego zamachu na dobra prawne jej uczestnika" ${ }^{36}$. A. Marek także zwraca uwagę na to, że uczestnicy bójki co do zasady nie moga powoływać się na działanie w obronie koniecznej, gdyż „Wynika to z konstrukcji bójki, która polega na czynnym starciu się co najmniej trzech osób, z których każda występuje zarówno w roli napastnika, jak i napadniętego" ${ }^{37}$. Również K. Wiak stwierdza, że „[...] uczestnicy bójki z zasady nie moga powoływać się na obronę konieczna, gdyż wszyscy realizuja zachowania stanowiace bezprawny zamach na dobro prawne"38. Stanowisko to popiera także M. Budyn-Kulik, uznając, że „Uczestnikom bójki w zasadzie nie przysługuje prawo do obrony koniecznej” 39 oraz Lech Gardocki ${ }^{40}$. L. Wilk zauważa, że: „Warunek bezprawności zamachu przesądza [...] zasadniczo o niedopuszczalności obrony koniecznej w bójce, w której każdy jej uczestnik jest jednocześnie atakującym i broniącym się [...]. Dopóki dana osoba uczestniczy w bójce pozbawiona jest prawa do obrony koniecznej. Działający bowiem w obronie koniecznej działa prawnie, tymczasem każdy, kto uczestniczy w bójce, czyli wzajemnym starciu co najmniej trzech osób, działa bezprawnie. Występując w podwójnej roli (zarówno atakującego, jak i broniącego się) nie może powoływać się na obronę konieczna, wszyscy bowiem uczestnicy bójki sa w tej samej sytuacji, a obrona konieczna przeciwko obronie koniecznej jest niedopuszczalna" ${ }^{41}$. Również Sąd Apelacyjny w Krakowie w wyroku z 26 marca 2013 r. (II AKa 27/13) uznał, że „Oskarżony uczestniczył w bójce, co wyłącza możliwość powoływania się na działanie w obronie koniecznej, bo uczestnicy

\footnotetext{
${ }^{35}$ R. Góral, op. cit., s. 46.

${ }^{36}$ P. Daniluk, w: R. A. Stefański (red.), Kodeks karny. Komentarz, Warszawa 2015, s. 236.

${ }^{37}$ A. Marek, Obrona konieczna w prawie karnym. Teoria..., s. 75.

${ }^{38}$ K. Wiak, op. cit., s. 683.

${ }^{39}$ M. Budyn-Kulik, op. cit., s. 400.

${ }^{40}$ L. Gardocki, Prawo karne, Warszawa 2015, s. 122.

${ }^{41}$ L. Wilk, op. cit., s. 146.
} 
bójki występują w podwójnej, ofensywno-defensywnej roli, realizując bezpośredni, bezprawny zamach na dobra prawem chronione innych uczestników zajścia”.

Warto w tym miejscu zwrócić uwagę na wyrok Sądu Najwyższego z 28 lutego 1935 r. (II K 1697/34), w którym Sąd ten stwierdził, że: „Zawinienie udziału w bójce wyklucza obronę konieczną tylko odnośnie do samego karalnego udziału w bójce. Natomiast odnośnie do konkretnego zawinionego urazu cielesnego w każdej bójce może zachodzić stan obrony koniecznej [...] Ten nawet, kto bójkę zawinił, może w czasie jej trwania znaleźć się w sytuacji uprawniającej do obrony koniecznej”. Zdaniem Władysława Woltera takie rozróżnienie obrony w samej bójce i obrony przed konkretnym ciosem prowadzi do rozczłonkowania sytuacji uczestnika bójki „raz na napastnika, raz na napadniętego, podczas kiedy w ramach bójki jest on jednym i drugim, chociaż naturalnie nie równocześnie" ${ }^{42}$.

Choć zasadą jest, że uczestnikowi bójki nie przysługuje prawo do obrony koniecznej, istnieją w moim przekonaniu pewne sytuacje, w których dopuszczalne jest powoływanie się przez niego na ten kontratyp. Przede wszystkim uznać należy, że uczestnik bójki odzyskuje prawo do obrony koniecznej z chwila, gdy wycofa się on z udziału w tej bójce, jednakże nie sposób nie zauważyć, że w momencie, gdy nastapi wycofanie się przez uczestnika bójki z udziału w niej, osoba taka przestaje być już jej uczestnikiem. Dlatego też, moim zdaniem, przyjąć trzeba, że uczestnikowi bójki nie przysługuje prawo do obrony koniecznej wobec pozostałych jej uczestników jedynie dopóty, dopóki on sam bierze w tej bójce udział, albowiem z chwila, gdy nastapi wycofanie się przez uczestnika bójki z udziału w niej, a mimo to pozostali uczestnicy w dalszym ciagu będą dopuszczać się wobec niego zamachu, zamach ten będzie miał cechę bezprawności i o ile będzie on jednocześnie spełniał pozostałe warunki, tj. będzie on zamachem rzeczywistym oraz bezpośrednim, osoba, która się z bójki wycofała, będzie mogła powołać się na działanie w obronie koniecznej, odpierając tenże zamach. Sąd Najwyższy w swoim wyroku z 11 października 1938 r. (I K 2760/38), uznał, że „Uczestnik bójki nie może zasłaniać się obrona konieczna, jak długo działanie jego ma charakter zarówno ofensywny, jak defensywny”. Taki pogląd prezentuje także Andrzej Zoll, stwierdzając, że: „Bezprawnym zamachem jest działanie wszystkich uczestników bójki. Wobec tego dopóki trwa udział w bójce, dopóty żadnemu z uczestników bójki nie przysługuje prawo do obrony koniecznej. Każdy jest bowiem napastnikiem dokonującym zamachu bezprawnego" ${ }^{43}$. Ten sam autor uznaje, że „Prawo do obrony koniecznej będzie przysługiwało dopiero po odstapieniu od aktywnego uczestniczenia w bójce i przejściu na pozycje wyłącznie obronne. Osoba znajdująca się w takiej sytuacji przestaje już być uczestnikiem bójki”" ${ }^{44}$. Również Paweł Daniluk stoi na stanowisku, iż: „Przyjąć należy, że osoba odzyskuje prawo do obrony koniecznej z chwilą wycofania się z bójki. W tym momencie przestaje bowiem być jej uczestnikiem i jeżeli - mimo to - nadal jest atakowana, wów-

${ }^{42}$ W. Wolter, Prawo karne. Zarys wyktadu systematycznego, Warszawa 1947, s. 198-199.

${ }^{43}$ A. Zoll, w: idem (red.), Kodeks karny. Część ogólna, Komentarz Lex, Warszawa 2012, s. 456.

${ }^{44}$ Ibidem, s. 457. 
czas może podjąć czynności obronne w warunkach art. $25 \S 1$ KK" ${ }^{45}$. J. Warylewski podkreśla z kolei, że: „Tylko zaprzestanie walki i wycofanie się z bójki, a następnie występowanie wyłącznie w charakterze defensywnym, umożliwia skorzystanie z prawa do obrony koniecznej”"46.

Pamiętać jednak należy, że chodzi tu tylko i wyłącznie o ostateczne i rzeczywiste wycofanie się z bójki, a nie o takie wycofanie się, które określić można jako taktyczne, a zatem takie, które ma na celu na przykład zajęcie lepszej pozycji do ataku, jaki ma być następnie ponownie podjęty. Stanowisko to zyskało potwierdzenie w wyroku Sądu Najwyższego z 20 grudnia 1984 r. (akt II KR 289/84), w którym to wyroku SN stwierdził, że: „W sytuacji gdy uczestnik bójki wycofuje się z niej i jest potem atakowany, wówczas uzyskuje prawo do obrony koniecznej, gdyż osoba, która nie bierze już udziału w bójce przestaje być jej uczestnikiem, a w takiej sytuacji atak na nią należy ocenić, jako bezprawny zamach, do którego odparcia uprawniony jest każdy atakowany. Wymaga to jednak dokładnej oceny, czy wspomniane wycofanie się jest faktyczne, a nie pozorowane względami taktycznymi dla uzyskania lepszej pozycji do ponowienia ataku. To ostatnie wycofanie się bowiem nie uprawnia do obrony koniecznej”.

Nie trudno w moim przekonaniu wyobrazić sobie również sytuację, kiedy to kilka osób bierze udział w bójce i podczas jej trwania jeden z uczestników lub też kilkoro z nich zostanie zaatakowanych przez inną osobę, czy też grupę osób, które udziału w tejże bójce nie biora. W przypadku takiego ataku „z zewnątrz" na uczestnika bójki, czy też na kilku jej uczestników, zaatakowanemu uczestnikowi przysługuje prawo do obrony koniecznej, jeśli zamach ten będzie zamachem rzeczywistym, bezpośrednim oraz bezprawnym.

Inną sytuacja, w której uczestnikowi bojki przysługiwać będzie prawo do obrony koniecznej wobec pozostałych jej uczestników jest sytuacja, kiedy to dojdzie do istotnego zwiększenia niebezpieczeństwa bójki. Pogląd taki prezentuje m.in. P. Daniluk, twierdząc, że: „Wydaje się, że należy także dopuścić możliwość powołania się na obronę konieczną w specyficznych sytuacjach, kiedy niektórzy uczestnicy bójki istotnie zwiększają jej niebezpieczeństwo. $\mathrm{Z}$ taka sytuacją będziemy mieli do czynienia np. wówczas, gdy podczas starcia na pięści kilku osób, jedna z nich wyciaga nóż z zamiarem jego użycia. [...] W takich okolicznościach nie można odmawiać prawa do obrony koniecznej tym uczestnikom bójki, którzy podejmą czynności obronne wobec używającego noża”" ${ }^{47}$. Również K. Wiak podkreśla, iż „W literaturze został [...] wyrażony pogląd o prawie do obrony uczestnika bójki »niegroźnej dla życia« wobec uczestnika, który ucieka się do zamachu "groźnego dla życia», np. sięga po broń" ${ }^{48}$. Potwierdza to także wyrok Sądu Apelacyjnego w Krakowie z 5 grudnia 2003 r. (II AKa 256/03), w którym Sąd ten stwierdził, że „[...] podczas wzajemnej bijatyki może powstać sytuacja, która uprawni jedną ze stron do działania w obronie koniecznej, jak sięgnięcie przez jednego z adwersarzy po broń, nóż itp.”.

\footnotetext{
${ }^{45}$ P. Daniluk, op. cit., s. 237.

${ }^{46}$ J. Warylewski, Prawo karne. Część ogólna, Warszawa 2012, s. 264.

${ }^{47}$ P. Daniluk, op. cit., s. 236-237.

${ }^{48}$ K. Wiak, op. cit., s. 683.
} 
Warto w tym miejscu zwrócić uwagę na to, co podkreśla A. Marek, a mianowicie, że „Wielu autorów wyraża pogląd, że jeżeli bójka nie miała charakteru niebezpiecznego (np. walka na pięści), to nie można odmówić prawa do obrony koniecznej temu jej uczestnikowi, który nagle zostaje zagrożony jej zaostrzeniem, np. wskutek sięgnięcia przez innego uczestnika bójki po nóż lub inne niebezpieczne narzędzie. Teza ta generalnie jest słuszna, ale wymaga pewnego komentarza. Obowiązujący k.k. - podobnie jak k.k. z 1969 r. - uznaje za przestępstwo tylko udział w niebezpiecznej bójce lub pobiciu, tj. w takim zajściu, w którym naraża się człowieka na bezpośrednie niebezpieczeństwo utraty życia lub ciężkiego uszkodzenia ciała (art. 158 § 1). W założeniu więc bójka (lub pobicie) muszą mieć charakter niebezpieczny, aby wchodziły w orbitę zainteresowania prawa karego. Wynika stąd pytanie, czy w niebezpieczniej bójce zasadne jest rozróżniać takie jej zaostrzenie, które uprawniałoby do obrony koniecznej? Na to pytanie należałoby odpowiedzieć twierdząco, ale pod warunkiem, że obrona dotyczyć będzie drastycznego zaostrzenia niebezpieczeństwa bójki, tj. sytuacji konkretnego, bezpośredniego zamachu na życie lub zagrażającego ciężkim uszkodzeniem ciała jej uczestnika (np. jeden z uczestników bójki podbiega z tyłu do niewidzącego go innego uczestnika z łomem, aby uderzyć go w głowę)" ${ }^{49}$. Sąd Najwyższy w swoim wyroku z 7 kwietnia 1975 r. (II KR 10/75) stwierdził, że „Podmiotem przestępstwa z art. $158 \S 1$ k.k. [Kodeks karny z 1969 r. - przyp. P.B.] jest każdy, kto umyślnie bierze w jakikolwiek sposób udział w bójce [...], niezależnie od tego, czy jego osobisty udział wykazuje cechy działania niebezpiecznego dla życia człowieka lub jego zdrowia w takim stopniu, jak określony w art. 155 k.k. [Kodeks karny z 1969 r. - przyp. P.B.]. Odpowiedzialność za udział w bójce [...] ma charakter wspólnej odpowiedzialności, z tym że każdy uczestnik musi mieć świadomość niebezpiecznego charakteru tego zbiorowego zatargu". W. Wolter zauważa natomiast, że „[...] bójka lub pobicie [...] mogą być niebezpieczne nie tylko dlatego, że użyto niebezpiecznych narzędzi, ale również ze względu na warunki, w jakich miały miejsce (np. na schodach kamiennych, w pobliżu jezdni, ze względu na odbywajacy się tam ruch pojazdów mechanicznych itp.)" ${ }^{50}$.

$\mathrm{Na}$ to, że „Pewne problemy rodzić może włączenie się do bójki osoby trzeciej celem jej zakończenia, czy też ograniczenia skutków" ${ }^{1}$, zwraca uwagę P. Daniluk. Zdaniem tego autora: „Osoba trzecia, która włącza się do bójki celem jej zakończenia czy też ograniczenia skutków może powoływać się na obronę konieczna, bowiem nie towarzyszy jej zamiar atakowania dóbr prawnych, lecz likwidacji bezprawnego starcia" ${ }^{52}$. Stanowisko to podziela także L. Wilk ${ }^{53}$. Również J. Warylewski zauważa, że: „Z prawa do obrony koniecznej może [...] skorzystać osoba postronna, która ma zamiar bójce zapobiec lub ją zakończyć np. poprzez rozdzielenie bijących się stron [...]" ${ }^{54}$. Sąd Najwyższy w wyroku

\footnotetext{
49 A. Marek, Obrona konieczna w prawie karnym. Teoria..., s. 81-82.

50 W. Wolter, Kodeks karny. Przestepstwa przeciwko życiu i zdrowiu, Warszawa 1970, s. 23.

51 P. Daniluk, op. cit., s. 237.

52 Ibidem.

53 L. Wilk, op. cit., s. 146.

${ }^{54}$ J. Warylewski, Prawo karne..., s. 264.
} 
z 26 lipca 1971 r. (IV KR 119/71) orzekł, że „[...] osoba postronna, która nie angażujac się po stronie któregokolwiek z bioracych udział w bójce, a więc nie będąc jej uczestnikiem, stara się jej zapobiec w jakikolwiek sposób, np. przez rozdzielenie bijących się, odebranie im niebezpiecznych narzędzi, rozpędzenie ich itd., działa w obronie koniecznej. Natomiast nie działa w obronie koniecznej ten, kto włącza się do bójki w celu przyjścia z pomoca jednemu z jej uczestników, gdyż w ten sposób powiększa krąg bijących się osób, potęgując tym samym niebezpieczeństwo dla życia i zdrowia uczestników zajścia lub znajdujących się w pobliżu osób”.

Z kolei w wyroku z 2 kwietnia 2009 r. (IV KK397/08) Sąd Najwyższy stanął na stanowisku, iż „Nie można przyjąc działania w celu zapobieżenia bójce, gdy osoba postronna, interweniujac c w niej w celu udzielenia pomocy jednemu z jej uczestników, po odparciu zamachu na nią samą przez innego z uczestników bójki, goniąc go, gdy ten już oddala się z miejsca zdarzenia, bije go dalej, a następnie, gdy ucieka on samochodem, wsiada w swój pojazd i kontynuuje pościg, nie interesując się przebiegiem zdarzenia odnośnie pozostałych uczestników bójki. Tego typu działanie jest w istocie włączeniem do bójki jedynie dla niesienia pomocy jednemu z jej uczestników, a nie działaniem przeciw bójce, przy którym może wchodzić w grę obrona konieczna”.

W przypadku osoby postronnej, która występuje przeciwko bójce wyłącznie w celu jej zakończenia, czy też ograniczenia jej skutków trudno, w moim przekonaniu, mówić o włączeniu się takiej osoby do bójki, albowiem poprzez włączenie się do bójki należy, moim zdaniem, rozumieć tylko takie zachowanie, którego celem jest branie aktywnego udziału w bójce. W sytuacji gdy osoba trzecia podejmuje pewne działania zmierzające jedynie do zakończenia bójki, nie można mówić, że osoba ta do niej się włącza, a co za tym idzie nie można takiej osoby określić mianem uczestnika bójki. Pomimo że osoba taka przez swoją interwencję przeciwko bójce nie staje się w żadnym razie jej uczestnikiem, to w przypadku, gdy zostanie ona zaatakowana przez któregokolwiek z uczestników toczącej się bójki, przysługiwać jej będzie niewątpliwie prawo do odparcia bezprawnego i bezpośredniego zamachu w ramach obrony koniecznej. Potwierdza to wyrok Sądu Najwyższego z 28 lutego 1963 r. (V K 343/62), w którym Sąd ten stwierdza, że „Udział w bójce lub pobiciu bierze ten, kto przyłącza się do grona bijaccych się z zamiarem czynnego udziału $\mathrm{w}$ nieprzyjaznym starciu z innym uczestnikiem zwady. Nie bierze natomiast udziału w bójce lub pobiciu ten, kto włącza się do grona bijących się jedynie i wyłącznie w celu przeszkodzenia biciu się i zapobieżenia skutkom zbiorowej niebezpiecznej bijatyki np. przez rozdzielenie bijących się i niedopuszczenie do kontynuowania bijatyki. Takie włączenie się do grona bijacych się, podyktowane wspomnianym wyżej celem nie wyłącza użycia przez włączającego się siły, pod warunkiem jednak, że będzie ona użyta jedynie i wyłącznie do przeszkodzenia bijatyce i w celu niedopuszczenia do jej kontynuowania”.

M. Konieczny postuluje rozróżnienie osób biorących udział w bójce dobrowolnie, które do niej przystapiły z zamiarem aktywnego uczestnictwa od osób, które znalazły się w bójce bez zamiaru uczestniczenia w niej, czy też zostały zaatakowane przed rozpoczęciem bójki lub po wycofaniu się z niej. Tej drugiej 
grupie osób przysługiwać powinno prawo do obrony koniecznej ${ }^{55}$. Jak zauważa A. Zoll: „,...] należy przyjąć, że działa w obronie koniecznej ten, kto występuje przeciwko bójce w celu jej zakończenia (likwidator bójki). Osoba taka występuje bowiem w obronie życia lub zdrowia uczestników bójki i w obronie zakłóconego spokoju publicznego oraz naruszonego porządku prawnego. Warunkiem przyjęcia obrony koniecznej jest działanie przeciwko bójce jako całości, a nie przeciwko poszczególnym jej uczestnikom w celu niesienia pomocy pozostałym" ${ }^{56}$. Igor Andrejew zwraca jednak uwagę na to, że „Granica między uczestnikiem bójki a osobą interweniująca w celu jej zakończenia lub ograniczenia jest w praktyce trudno uchwytna. Osoba interweniująca jest w trudnej sytuacji, zwłaszcza, gdy bójka odbywa się w środowisku ludzi mało kulturalnych" ${ }^{57}$. Podkreśla to także Mirosław Surkont ${ }^{58}$. Również Włodzimierz Wróbel oraz Andrzej Zoll wskazuja, że: „Trzeba sobie zdawać sprawę z bardzo poważnych trudności w odróżnieniu likwidatora bójki od jej aktywnego uczestnika" ${ }^{59}$.

Warto w tym miejscu przytoczyć słowa M. Cieślaka, który w kwestii prawa uczestnika bójki do powoływania się na kontratyp obrony koniecznej wypowiedział się w sposób następujący „[...] uczestnicy bójki, jako - ogólnie biorąc - atakujący i broniący się równocześnie, nie mogą się w zasadzie powoływać na obronę konieczna w stosunku do siebie. Od tej reguły istnieją trzy wyjątki: 1) ten, kto interweniuje w celu przywrócenia porządku nie jest uczestnikiem bójki, działa [...] legalnie, w stanie obrony koniecznej; 2) ten, kto wyraźnie wycofał się z bójki, nie jest już jej uczestnikiem i od tej pory uzyskuje prawo do obrony koniecznej - także w stosunku do atakującego go interweniującego; 3) uczestnik bójki niegroźnej dla życia uzyskuje prawo do obrony koniecznej wobec uczestnika, który ucieka się do zamachu groźnego dla życia (np. sięga po broń palną, nóż, czy inne niebezpieczne narzędzie)"60.

Reasumując, wskazać należy, że choć co do zasady uczestnikom bójki nie przysługuje prawo do powoływania się na działanie w obronie koniecznej, albowiem uczestnicząc w niej, występują oni w podwójnej roli - atakujących oraz atakowanych i tym samym dopuszczają się oni bezprawnego zamachu na dobra prawne pozostałych jej uczestników, to jednak istnieją sytuacje, w których ich prawo do działania w obronie koniecznej się aktualizuje. Jedna z takich sytuacji jest ostateczne i rzeczywiste odstapienie od udziału w bójce, które skutkuje tym, że osoba odstępująca przestaje być uczestnikiem bójki i o ile pomimo swojego odstapienia zostanie ona zaatakowana przez któregokolwiek z jej uczestników, a zamach ten będzie spełniał warunek bezprawności, a także bezpośredniości, osobie tej przysługiwać będzie prawo do działania w obronie koniecznej celem odparcia tegoż zamachu. Również w sytuacji, gdy którykolwiek z uczestników bójki zostanie zaatakowany przez osobę trzecią która

\footnotetext{
55 M. Konieczny, Obrona konieczna a udziat w bójce, „Nowe Prawo” 1962, nr 2, s. 219-220.

56 A. Zoll, w: idem (red.), Kodeks karny..., s. 457.

${ }^{57}$ I. Andrejew, Polskie prawo karne w zarysie, Warszawa 1971, s. 174.

58 M. Surkont, Prawo karne, Gdynia 2001, s. 101.

${ }_{59}$ W. Wróbel, A. Zoll, Polskie prawo karne. Część ogólna, Kraków 2010, s. 351.

${ }^{60}$ M. Cieślak, op. cit., s. 222.
} 
udziału w toczącej się bójce nie bierze, będzie on mógł powołać się na działanie w obronie koniecznej w celu odparcia skierowanego przeciwko niemu zamachu. Prawo uczestnika bójki do powołania się na kontratyp obrony koniecznej aktualizuje się ponadto w momencie, gdy dojdzie do istotnego zwiększenia niebezpieczeństwa bójki, a zatem m.in. w sytuacji, gdy podczas toczącego się starcia jedna z osób wyciagnie nóż z zamiarem jego użycia. Możliwość powołania się na działanie w obronie koniecznej będzie miała również osoba postronna, która występuje przeciwko toczącej się bójce w celu jej zakończenia lub ograniczenia jej skutków. Mimo że osoba ta nie jest uczestnikiem bójki, to w sytuacji gdy zostanie ona zaatakowana przez którąkolwiek z osób uczestniczących w bójce, będzie mogła odeprzeć skierowany przeciwko niej zamach, powołując się przy tym na fakt, iż działała w obronie koniecznej.

mgr Paulina Banaszak

Uniwersytet Szczecinski

paulinabanaszak1305@op.pl

THE DEFENCE OF NECESSITY AND THE CRIME OF FIGHTING

Sum mary

One of the most controversial issues regarding a defence of necessity is the question whether the participant in the fight may to invoke this circumstance. Before analysing this issue, the author first characterised the defence of necessity and the crime of fighting. These aspects have not been fully explained so far due to many controversies, and the aim of this article was to identify the fundamental problems concerning this issue and to present the opinions of Polish criminal law doctrine as well as selected decisions delivered by common courts. An attempt was also made to decide whether a participant in the fight may invoke the action in the defence of necessity. The main conclusion of the article is that in some situations the person who takes part in the fight acts in a defence of necessity. 
